\title{
CHANGES, CHALLENGES, RESPONSIBILITY
}

\section{International Geographical Union Regional Conference (Kraków, Poland, 18 $^{\text {th }}-2^{\text {th }}$ August, 2014)}

The 2014 Regional Conference of the International Geographical Union was held at the Jagiellonian University in Krakow, Poland, on $18^{\text {th }}-22^{\text {th }}$ August 2014. It was titled "Changes, Challenges, Responsibility". As 2014 marked both the 650th anniversary of the founding of the Jagiellonian University and the $80^{\text {th }}$ anniversary of the $14^{\text {th }}$ IGU Congress organised in Warsaw, the 2014 IGU RC in Krakow was deemed to have a special dimension when it came to the promotion of Polish geographical research worldwide, as well as the bringing together in Poland of geographers from around the globe.

The eight Polish geographical institutions forming the consortium of Conference organisers were:

- the Polish Geographical Society;

- the Institute of Geography and Spatial Management of the Jagiellonian University;

- the Institute of Geography of the Pedagogical University of Cracow;

- the Faculty of Geographical and Geological Sciences of the Adam Mickiewicz University in Poznań;

- the Warsaw-based Institute of Geography and Spatial Organization of the Polish Academy of Sciences;

- the Faculty of Geographical Sciences of the University of Łódź;

- the Faculty of Earth Sciences of the Silesian University in Sosnowiec;

- the Faculty of Geography and Regional Studies of the University of Warsaw.

Honorary patronage of the IGU2014 was assumed by President of the Republic of Poland Bronisław Komorowski. Members of the Honorary Committee in turn included Prof. Vladimir Kolosov, President of the International Geographical Union, Prof. Michał Kleiber, President of the Polish Academy of Sciences, Prof. Jacek Majchrowski, Mayor of the City of Krakow, and Prof. Wojciech Nowak, Rector of the Jagiellonian University. 
In the event, the Conference attracted no fewer than 1372 participants from 60 countries, including 416 delegates from Poland. Other states that were particularly well-represented at the event included Germany, Japan, the Czech Republic, the United Kingdom and China.

The main Conference activities consisted of Plenary Sessions, Sessions of the IGU Commissions, and Subject-related Sessions with oral and poster presentations. The Subject-related Sessions saw a total of 1171 oral presentations given, with some 227 posters also on display. There were 226 core Conference Sessions organised by the different IGU Commissions, 19 Joint Sessions organised by two or more IGU Commissions, and 47 Sessions organised by Conference participants. Each Session comprised three to a maximum of five oral presentations.

Several accompanying events were also organised, including pre-Conference meetings and Seminars of the IGU Commissions, IGU Commission business meetings held during the Conference, the $11^{\text {th }}$ International Geography Olympiad, an exhibition entitled "The Development of Geographical Ideas in Poland" put on at the Museum of the Jagiellonian University, exhibitions and workshops, academic excursions, tourist tours around Krakow and its environs, and a variety of social events.

The Conference brought together geographers from throughout the world, with a view to a major contribution being made to our better joint understanding of the changes and challenges the world faces, as well as the responsibility in the face of these that geography as a discipline bears and shares. That discipline is indeed seen to face significant challenges centering around the detection of contemporary changes taking place in the environment, society and the economy.

On each Conference day, one of the key themes (Changes, Challenges or Responsibility) was presented by way of Plenary Lectures. Signals in respect of the Conference title's CHANGES were addressed during the Plenary Session of $19^{\text {th }}$ August 2014, the Plenary Lecture on "2016: The UN International Year of Global Understanding (IYGU) - The UN International Year of Geography" being given by Prof. Benno Werlen. The Plenary Lecture was followed by several Subject-related sessions dealing with environmental change in the form of landscape fragmentation, land degradation, climate change and the impacts of variability. Political, economic and social aspects were also introduced, the key issues in this case being the dynamics of economic space, migration, population change and the demographics of cities.

Issues as regards the titular CHALLENGES were in turn addressed at the Plenary Session of $20^{\text {th }}$ August. The Plenary Lecture from Prof. Zbigniew Kundzewicz concerned "Climate change, related challenges and responsibilities". The Plenary Lecture by Prof. Gideon Biger was in turn on "The Challenge of Historical Geography and the geographical question of "Where is the Holy Land"? Otherwise, the main focus of lectures was on natural and social aspects to the global issues impacting on the local environment and communities.

It was during the August $21^{\text {st }}$ Plenary Session that RESPONSIBILITY issues in respect of observed changes were considered by way of lectures from Profs Julie Winkler 
("Embracing the Complexity and Uncertainty of Climate Change: Responsibilities for Geographers") and Andreas Faludi ("Place is a no-man's land, so who is responsible?"). Challenges arising in a complex world were discussed in the contexts of resilience and the generation of sustainability. Responsibility issues were likewise addressed at a session entitled "Science and GIS - Changing Approaches, Challenging Problems and Responsible Science".

The IGU 2014 Conference achieved its intended aims of assembling geographers and earth scientists from around the world, taking stock of where geography as a discipline stands in that complex world, and helping to augment linkage and opportunities for cooperation. Indeed, the event was organised to near-perfection by the local Organising Committee of the Jagiellonian University's Institute of Geography and Spatial Management under the guidance of Mrs Anita Bokwa, Associate Professor at the Jagiellonian University. The event was thus a massive success that made a tangible further contribution to the integration of the geographical community internationally. A big thank you is definitely in order!

Urszula Somorowska

Faculty of Geography and Regional Studies University of Warsaw 